Shamayim: Jurnal Teologi dan Pendidikan Kristiani

Volume 1, Nomor 1, 2020 (45-57)

http://hologos.college/ejournal/index.php/shamayim/index

\title{
Tinjauan Teologis Tentang Gereja Sejati dan Aplikasinya Bagi Pelayanan Gereja Kontemporer
}

\author{
Paulus Purwoto \\ Sekolah Tinggi Teologi Torsina, Indonesia \\ pauluspurwoto022@gmail.com
}

\begin{abstract}
The church is a chosen group or congregation, namely those who are called by God to come out of the world, go away from sin and enter into the realm of grace. The church has a relationship with God's people in the Old Testament, where in the Old Testament God chose Abraham as the embryo of the birth of the nation of Israel, which was God's chosen nation. Theologically, the idea of God's people being called out clearly existed in Old Testament times, as well as in New Testament times. Linguistically the Greek word ekklesia appears repeatedly in connection with Israel in the Septuagint translation. The elements in the Old Testament exist in the New Testament church, however, they cannot be correctly equated between the Old Testament congregation and the church, because the church is a new product, founded on the Lord Jesus, made by the Holy Spirit and contains people from all the races of all nations become one new people of God. The true church has the signs as described in the Word of God. The purpose of this research is to conduct a theological review of the true church and its application to the contemporary church. The method used in this research is literature study method. The true church has signs, joy, holiness, truth, mission, unity, love, proclaims the Word of God properly, uses the sacraments properly, and exercises church discipline. The conclusion of this study is that the true church has signs that can be applied in contemporary church ministry.
\end{abstract}

Key words: Chruch, Contemporer, True, Ministry

\begin{abstract}
Abstrak
Gereja adalah kumpulan atau jemaat pilihan, yaitu mereka yang dipanggil Allah keluar dari dunia, pergi dari dosa dan masuk ke dalam wilayah anugerah. Gereja memiliki relasi dengan umat Allah dalam Perjanjian Lama, dimana dalam Perjanjian Lama Tuhan memilih Abraham sebagai embrio lahirnya Bangsa Israel yang merupakan bangsa pilihan Allah. Secara teologis gagasan tentang umat Allah yang dipanggil keluar jelas telah eksis pada masa Perjanjian Lama, sebagaimana pada masa Perjanjian Baru. Secara linguistik
\end{abstract}


kata Yunani ekklesia muncul berulang kali dalam kaitannya dengan Israel dalam terjemahan Septuaginta. Unsur-unsur dalam Perjanjian Lama tersebut ada dalam gereja Perjanjian Baru, namun demikian tidak dapat disamakan dengan tepat antara Jemaah Perjanjian Lama dengan gereja, oleh karena gereja adalah sesuatu produk baru, didirikan diatas Tuhan Yesus, dijadikan oleh Roh Kudus dan berisi orang-orang dari segala ras dari seluruh bangsa menjadi satu umat Allah yang baru. Gereja sejati memiliki tanda-tanda sebagaimana dijelaskan dalam Firman Tuhan. Tujuan penelitian ini adalah untuk melakukan tinjauan teologis tentang gereja sejati dan aplikasinya bagi gereja kontemporer. Metode yang digunakan dalam penelitian ini adalah metode studi literatur. Gereja sejati memiliki tanda-tanda, sukacita, kekudusan, kebenaran, misi, kesatuan, kasih, memberitakan Firman Tuhan dengan benar, menggunakan sakramen dengan benar, dan menjalankan disiplin gereja. Kesimpulan dari penelitian ini adalah bahwa gereja sejati memiliki tanda-tanda yang dapat diaplikasikan dalam pelayanan gereja kontemporer.

Kata kunci: Gereja, Kontemporer, Sejati, Pelayanan.

\section{Pendahuluan}

Gereja adalah kumpulan atau jemaat pilihan, yaitu mereka yang dipanggil Allah keluar dari dunia, pergi dari dosa dan masuk ke dalam wilayah anugerah. ${ }^{1}$ Berdasarkan penelitian yang terdahulu yang dilakukan oleh Zaluchu, yang merumuskan karakteristik gereja mula-mula yang merupakan salah satu tanda khas gereja sejati. ${ }^{2}$ Gereja memiliki relasi denagn umat Allah dalam Perjanjian Lama, dimana dalam Perjanjian Lama Tuhan memilih Abraham sebagai embrio lahirnya Bangsa Israel yang merupakan bangsa pilihan Allah. Fakta tersebut menunjukkan mengenai permulaan terbentuknya jemaat Perjanjian Lama, dimana dalam kisah tersebut inisiatif seluruhnya bersumber dari Allah. Allah-lah yang mencari dan memanggil Abraham, bukan sebaliknya Abraham yang mencari Allah (Kej. 12:1-2).

Gereja yang adalah ciptaan Kristus dalam sejarah, memiliki akar dalam Perjanjian Lama dan tidak mungkin dipahami dengan tepat tanpa latar belakang itu. James M. Boice menulis bahwa secara teologis pandangan tersebut benar karena gagasan tentang umat Allah yang dipanggil keluar jelas telah eksis pada masa Perjanjian Lama, sebagaimana pada masa Perjanjian Baru. ${ }^{3}$ Secara linguistik pandangan diatas juga benar, karena kata Yunani ekklesia muncul berulang kali dalam kaitannya dengan Israel dalam terjemahan Septuaginta. Dalam Septuaginta, ekklesia pada umumnya menerjemahkan kata Ibrani qhl

1 R.C. Sproul, Kebenaran-Kebenaran Dasar Iman Kristen, Cetakan Ke. (Malang: Departemen Literatur SAAT, 2002, hlm. 285).

${ }^{2}$ Sonny Eli Zaluchu, "Eksegesis Kisah Para Rasul 2:42-47 Untuk Merumuskan Ciri Kehidupan Rohani Jemaat Mula-Mula Di Yerusalem," EPIGRAPHE: Jurnal Teologi dan Pelayanan Kristiani 2, no. 2 (2019): 72-82.

${ }^{3}$ James Montgomery Boice, Dasar-Dasar Iman Kristen (Foundations of Christian Faith), ed. Solomon Yo, Cetakan Ke. (Surabaya: Penerbit Momentum (Momentum Christian Literature), 2015), hlm. 654. 
merujuk kepada orang-orang yang dipanggil keluar untuk dikumpulkan oleh Allah sebagai miliknya yang istimewa. ${ }^{4}$ Hal tersebut terlihat jelas dalam frasa "hari perkumpulan" dalam Ulangan 9:10; 10:4; 18:16 yang menjelaskan tentang berkumpulnya bangsa Israil di Gunung Sinai. Ayat yang pararel dengan itu ada dalam Mazmur 22:23,26 yang diterjemahkan menjadi Jemaah. Ayat-ayat tersebut dikutib oleh Stefanus: "Musa inilah yang menjadi pengantara dalam sidang jemaah di padang gurun di antara malaikat yang berfirman kepadanya di gunung Sinai dan nenek moyang kita; dan dialah yang menerima firman-firman yang hidup untuk menyampaikannya kepada kamu." (Kisah Rasul 7:38)

Unsur-unsur dalam Perjanjian Lama tersebut ada dalam gereja Perjanjian Baru, namun demikian tidak dapat disamakan dengan tepat antara Jemaah Perjanjian Lama dengan gereja, oleh karena gereja adalah sesuatu produk baru. Lebih lanjut James M. Boice menjelaskan bahwa gereja memiliki ciri khusus diantaranya: didirikan diatas Tuhan Yesus, dijadikan oleh Roh Kudus dan berisi orang-orang dari segala ras dari seluruh bangsa menjadi satu umat Allah yang baru bernama gereja. ${ }^{5}$ Gereja merupakan anggur baru yang didalam kantong anggur yang baru juga (Matius 9:17). Senada dengan itu, Thiessen menulis bahwa gereja bukan kelanjutan sistem yang sudah kuno dengan alasan Israel dan gereja dalam Alkitab bukan istilah yang searti. ${ }^{6}$ Paulus membedakan antara orang Yahudi, orang Yunani dan jemaat atau gereja (1 Korintus 10:32). Gereja adalah manusia yang baru (Ef. 2:15; Kol. 3:11) yang terdiri atas orang Yahudi dan orang yang bukan Yahudi yang percaya.

Itulah sekilas tentang relasi antara umat Allah dalam Perjanjian Lama dengan gereja Perjanjian Baru, nyata bahwa unsur-unsur panggilan umat Perjanjian lama terdapat dalam gereja namun demikian gereja adalah produk baru dalam Tuhan Yesus yang maknanya melampaui umat Perjanjian Lama. Gereja yang adalah produk baru yang didirikan oleh Kristus memiliki tanda-tanda gereja sejati. Apa sajakah tanda-tanda gereja sejati dan apakah tanda-tanda gereja sejati tersebut dapat diaplikasikan dalam pelayanan gereja kontemporer? Melalui penulisan makalah ini penulis berusaha untuk menjawab berbagai pertanyaan diatas, dengan judul makalah: "Tinjauan Teologis Tentang Gereja Sejati dan Aplikasinya Bagi Pelayanan Gereja Masa Kini”.

\section{Metode Penelitian}

Penulisan ini menggunakan metode studi literatur. Penulis berusaha menjawab permasalahan penelitian dengan mencari sumber-sumber literatur yang berkorelasi dengan masalh penelitian. Sumber-sumber tersebut adalah buku teks, pendekatan tematis digunakan untuk melakukan tinjauan teologis tentang Gereja sejati dan aplikasinya bagi pelayanan gereja kontemporer. Kemudian penulis menganalisis sumber-sumber yang terkait dengan menggunakan analisis dokumen/analisis isi yang merupakan kajian yang

\footnotetext{
${ }^{4}$ Ibid.

${ }^{5}$ Ibid, hlm. 656.

${ }^{6}$ Henry C. Thiessen, Teologi Sistematika, Cetakan Ke. (Malang: Penerbit Gandum Mas Malang, 2010, hlm. 474).
} 
menitikberatkan interpretasi bahan tertulis berdasarkan konteksnya untuk mendapatkan jawaban atas masalah penelitian.

\section{Pembahasan dan Hasil}

\section{Gereja}

Kata Perjanjian Baru untuk gereja adalah ékklesiatikal” yang artinya mereka yang dipanggil keluar. Gereja dilihat sebagai kumpulan atau jemaat pilihan, yaitu mereka yang dipanggil Allah keluar dari dunia, pergi dari dosa dan masuk ke dalam wilayah anugerah. ${ }^{7}$ Di dunia Yunani kata ek-klesia dari kata kerja kaleo mula-mula berarti mereka yang dipanggil keluar, yaitu orang-orang merdeka (bukan budak-budak) yang dipanggil berhimpun untuk menghadiri rapat rakyat. Kata tersebut diadopsi untuk gereja yang dipanggil berhimpun, yaitu oleh Allah. ${ }^{8}$ Sejalan dengan definisi diatas, Ryrie menulis bahwa dalam bahasa Yunani, ekklesia berarti suatu perhimpunan dan biasa dugunakan dalam pengertian politik, bukan dalam pengertian keagamaan. ${ }^{9}$ Jikalau ditinjau dari asalusul kata, kata tersebut seharusnya diterjemahkan dipanggil bersama bukan dipanggil keluar.

Bertitik tolak dari definisi gereja secara etimologis tersebut, gereja bukanlah organisasi dari orang-orang yang mau mendirikan suatu perkumpulan untuk tujuan tertentu, melainkan perkumpulan orang-orang yang dipanggil berkumpul oleh Allah. Status gereja tersebut untuk membedakan diri mereka dari orang Yahudi dan untuk menyatakan mereka menjadi umat yang sejati, yang merupakan keluarga rohani Allah, persekutuan yang diciptakan oleh Roh kudus, berdasarkan karya pendamaian Allah. ${ }^{10}$ Namun demikian dalam perkembangannya, kata gereja digunakan dengan bermacam-macam arti oleh banyak orang. Kadang digunakan untuk menyebut struktur fisik bangunan, dan kadang dipergunakan untuk sebuah denominasi.

Definisi gereja dari berbagi sudut pandang, yaitu sudut pandang pemilihan, sudut pandang yang efektif dan dari sudut pandang baptisan dan pengakuan. Louis Berkhof menulis bahwa dari susut pandang pemilihan, gereja adalah persekutuan orang-orang pilihan atau coetus electorum definisi gereja mencakup semua orang yang menjadi anggota tubuh Kristus, tanpa memandang hubungan mereka sekarang dengan gereja. ${ }^{11}$ Dari sudut pandang panggilan yang efektif, gereja di definisikan sebagai persatuan orang-orang pilihan yang dipanggil oleh Roh Allah (coetus electorum vocatorum) sebagai tubuh dari

${ }^{7}$ R.C. Sproul, Kebenaran-Kebenaran Dasar Iman Kristen, Cetakan Ke. (Malang: Departemen Literatur SAAT, 2002, hlm. 285).

${ }^{8}$ B.J. Boland G.C. Van Niftrik, Dogmatika Masa Kini, ed. Staf Redaksi BPK Gunung Mulia, Cetakan ke. (Jakarta: BPK Gunung Mulia, 2015), hlm. 359.

${ }^{9}$ Charles C. Ryrie, Teologi Dasar 2, Cetakan Ke. (Yogyakarta: Yayasan Penerbit ANDI, 1986), hlm. 184.

${ }^{10}$ William W. Menzies dan Stanley M. Horton, Doktrin Alkitab, Cetakan ke. (Malang: Penerbit Gandum Mas Malang, 2003), hlm. 159.

${ }^{11}$ Louis Berkhof, Teologi Sistematika 5, ed. Rudy dan Hendry, Cetakan Ke. (Surabaya: Penerbit Momentum (Momentum Christian Literature), 2001), hlm. 30. 
mereka yang di panggil secara efektif (coetus vocatorum) atau sebagai persekutuan orangorang beriman (coetus fidelium). ${ }^{12}$ Sedangkan dari sudut pandang baptisan dan pengakuan, gereja adalah persekutuan dari mereka yang telah dibaptiskan dan mengakui pengakuan iman yang benar. ${ }^{13}$ Pandangan tersebut sejalan dengan definisi gereja menurut Calvin dalam Insitutes IV seperti dikutib Berkhof, gereja yang nampak adalah sejumlah besar orang yang menyebar diseluruh dunia, yang mengakui menyembah kepada satu Tuhan di dalam Kristus, disatukan dalam iman melalui baptisan, mengakui kesatuan mereka dalam doktrin dan kebaikan melalui Perjamuan Kudus serta percaya kepada Firman Tuhan. ${ }^{14}$

\title{
Gereja Universal, Gereja Kelihatan Dan Gereja Lokal.
}

Selain definisi diatas, gereja juga dapat didefinisikan sebagai gereja universal, gereja kelihatan dan gereja lokal. Ryrie menulis bahwa gereja universal adalah semua orang percaya di Surga dan di bumi, gereja kelihatan adalah gereja lokal yang tersebar di berbagai daerah dan gereja lokal adalah suatu perhimpunan tertentu yang bersekutu secara terus menerus di tempat tertentu. ${ }^{15}$ Dari berbagai definisi gereja diatas, penulis berpendapat bahwa gereja adalah kumpulan orang-orang yang dipanggil keluar ke dalam persekutuan dengan Kristus, yang secara aktif beriman dan menghayati kehidupan iman sesuai tuntunan Firman Tuhan dan pimpinan Roh Kudus, yang begabung dalam persekutuan universal di Surga dan dibumi, yang kelihatan dan yang berkumpul secara terus menerus dilokalitas tertentu.

\section{Tanda-tanda Gereja Sejati}

Sekalipun unsur-unsur Perjanjian Lama ada dalam gereja Perjanjian Baru, namun gereja memiliki ciri-ciri khusus karena gereja didirikan oleh tuhan Yesus, dijadikan oleh Roh Kudus dan berisi dari semua orang dari berbagai ras di seluruh dunia yang dipanggil dalam persekutuan dengan Allah. Gereja sejati yang didirikan oleh Kristus dan dijadikan oleh Roh Kudus haruslah memiliki tanda-tanda seperti Kristus, seperti tertulis dalam 1 Yohanes 4:17: "Dalam hal inilah kasih Allah sempurna di dalam kita, yaitu kalau kita mempunyai keberanian percaya pada hari penghakiman, karena sama seperti Dia, kita juga ada di dalam dunia ini." James Montgomery menulis bahwa berdasarkan teks doa Tuhan Yesus pada Injil Yohanes 17, terdapat enam tanda dari gereja sejati yaitu: sukacita (ay. 13), kekudusan (ay. 14-16), kebenaran (ay. 17), misi (ay. 18), kesatuan (ay. 21-23) dan kasih (ay. 26). Kehidupan gereja sejati tak dapat dilepaskan dengan tanda-tanda tersebut. ${ }^{16}$ Sementara itu Sproul menulis bahwa secara historis terdapat tiga tanda-tanda gereja sejati yaitu memberitakan Firman Tuhan dengan benar, menggunakan sakramen dengan institusi

\author{
${ }^{12}$ Ibid, hlm. 31. \\ 13 Ibid. \\ 14 Ibid. \\ ${ }^{15}$ Ryrie, Teologi Dasar 2, hlm. 186. \\ ${ }^{16}$ Boice, Dasar-Dasar Iman Kristen (Foundations of Christian Faith) hlm 665.
}


mereka, dan menjalankan disiplin gereja. ${ }^{17}$ Senada dengan Sproul, Berkhof menulis meskipun terdapat pertentangan dari teolog Reformed tentang tanda dari gereja yang sejati, dimana sebagian meyakini hanya satu tanda (Beza, Alested, Amesimus, Heidanus, Maresius), sebagaian lagi meyakini ada dua tanda (Calvin, Bullinger, Zanchius, Junius, Gomarus, Mastricht, a Marck) dan sebagian lagi meyakini terdapat tiga tanda (Hyperius, Martyr, Ursinus, Treclatius, Heidegger, Wendelimus). ${ }^{18}$ Soedarmo dalam buku Ikhtisar Dogmatika juga menulis pendapat yang sama dengan para pakar di atas, dimana ia berpendapat bahwa terdapat tiga ciri gereja yaitu pemberitaan yang murni akan Firman Tuhan, pelayanan yang murni akan sakramen dan adanya siasat gereja. ${ }^{19}$

Oleh sebab itu, mengingat betapa pentingnya untuk mengerti secara mendalam mengenai tanda-tanda gereja yang sejati, pernulis akan menginventarisir tanda-tanda gereja sejati tersebut. Adapun tanda gereja sejati yang penulis paparkan dalam penelitian ini merupakan kombinasi dari berbagai penulis. Beberapa pendapat dari para teolog menjadi kekayaan tersendiri yang layak di jadikan kriteria atau tanda-tanda dari gereja sejati.

\section{Hidup dalam Sukacita}

Tanda pertama dari gereja sejati yang disebutkan oleh Tuhan Yesus adalah Sukacita. Dalam Firman Tuhan tertulis: "Tetapi sekarang, Aku datang kepada-Mu dan Aku mengatakan semuanya ini sementara Aku masih ada di dalam dunia, supaya penuhlah sukacita-Ku di dalam diri mereka." (Yohanes 17:13). Dalam bahasa Yunani, kata kerja yang berarti girang atau bersukacita adalah chairein yang ditemukan sebanyak tujuh puluh dua kali. ${ }^{20}$ Sekalipun kata tersebut tidak saja dipakai oleh gereja namun juga bagi masyarakat secular, namun kata chairein lebih banyak dipakai oleh orang Kristen. Barclay seperti dikutib oleh Montgomery menulis bahwa...tidak ada kebajikan dalam kehidupan Kristen yang tidak dibuat bersinar dengan sukacita; tidak ada keadaan dan tidak ada kesempatan yang tidak diterangi dengan sukacita. Kehidupan yang tidak bersukacita bukanlah kehidupan Kristen, karena sukacita adalah satu konstanta di dalam resep kehidupan Kristen. ${ }^{21}$ Dalam Alkitab tertulis: "Semuanya itu Kukatakan kepadamu, supaya sukacita-Ku ada di dalam kamu dan sukacitamu menjadi penuh.” (Yoh. 15:11).

Tanda kedua dari gereja sejati adalah kekudusan, dimana ini merupakan yang ciri yang paling banyak disebutkan di dalam Firman Allah. ${ }^{22}$ Tuhan Yesus menghendaki gereja menjadi umat yang kudus (1 Pet. 2:9), karena tanpa kekudusan tak seorangpun dapat melihat Allah (Ibr. 12:14). Tanda ini tertulis dalam doa Yesus untuk gereja: "Aku tidak meminta, supaya Engkau mengambil mereka dari dunia, tetapi supaya Engkau melindungi mereka dari pada yang jahat. Mereka bukan dari dunia, sama seperti Aku bukan dari dunia.

\footnotetext{
${ }^{17}$ Sproul, Kebenaran-Kebenaran Dasar Iman Kristen, hlm 289.

${ }^{18}$ Berkhof, Teologi Sistematika 5, hlm. 48.

${ }^{19}$ R. Soedarmo, Ikhtisar Dogmatika, ed. Staff Redaksi BPK Gunung Mulia, Cetakan ke. (Jakarta: BPK Gunung Mulia, 2011), hlm. 225.

${ }^{20}$ Boice, Dasar-Dasar Iman Kristen (Foundations of Christian Faith), hlm. 666.

${ }^{21}$ Ibid.

${ }^{22}$ Ibid, hlm. 667.
} 
Kuduskanlah mereka dalam kebenaran; firman-Mu adalah kebenaran." (Yohanes 17:1516). Orang yang kudus artinya orag yang dipanggil keluar dan dipisahkan bagi Allah yang membentuk gereja Allah (Ro. 1:17; 1 Kor. 1:2; 2 Kor. 1:1; Ef. 1:1; Flp. 1:1).

Tanda Ketiga dari gereja sejati adalah kebenaran, dimana sukacita dan kekudusan Kristen amatlah bergantung kepada seberapa baik kita mengenal Firman Allah, seberapa baik mengenal dan mempraktikkan prinsip-prinsip dari pernyataan Allah yang tertulis. ${ }^{23}$ Tuhan Yesus berdoa: "Kuduskanlah mereka dalam kebenaran, firman-Mu adalah kebenaran" (Yohanes 17:17). Ray Stedmen seperti dikutip oleh James Montgomery menulis bahwa orang-orang Kristen haruslah menjadi realis-realis terhebat, karena realism mereka adalah realism dari kebenaran Allah. realism seturut natur kebenaran Allah tersebut akan membawa sukacita dan pengudusan yang lebih besar. ${ }^{24}$ Kebenaran merupakan tanda gereja Sejati yang didirikan oleh Tuhan Yesus Kristus.

Tanda keempat dari gereja sejati adalah misi, dimana gereja memandang kedalam dan menemukan sukacita, kekudusan dan kebenaran, melainkan gereja juga harus memandang keluar kepada dunia dan menemukan obyek misinya. ${ }^{25}$ Tuhan Yesus bersabda: "Sama seperti Engkau telah mengutus Aku ke dalam dunia, demikian pula Aku telah mengutus mereka ke dalam dunia; dan Aku menguduskan diri-Ku bagi mereka, supaya mereka pun dikuduskan dalam kebenaran. (Yohanes 17:18). Tuhan Yesus Menghendaki gereja yang didirikan-Nya menjadi gereja yang missioner, itulah tanda gereja sejati. Kata missioner berasal dari bahasa Latin 'misio' yang kata dasarnya dalam Perjanjian Baru ' $\varepsilon v \alpha \gamma \gamma \varepsilon \lambda \iota o v$ ' (evangelion) yang berarti Injil atau kabar kesukaan. Dari kata dasar ini timbul kata evangelizo ' $\varepsilon v \alpha \gamma \gamma \varepsilon \lambda \iota \zeta o$ ' yang berarti saya memberitakan Injil, dari kata ini timbul kata ' $\varepsilon v \alpha \gamma \gamma \varepsilon \lambda o \sigma$ ' (evangelos) yang berarti orang yang memberitakan Injil. Dengan demikian 'misioner' berarti orang-orang yang percaya sepenuh pada Injil dan berusaha sepenuh untuk menyebarkannya. ${ }^{26}$ Jadi jemaat missioner adalah kumpulan orangorang yang terpanggil/terpanggil berdasarkan anugrah Allah yang percaya sepenuh pada Injil dan berusaha sepenuh untuk memelihara atau mempertahankan semangat menyebarkan Injil. Dengan kualitas penginjilan yang baik, usaha untuk menjadikan gereja yang missioner dapat terwujud dengan baik. Memberitakan Injil kepada dunia adalah perintah Perjanjian Baru, Injil harus diberitakan kepada semua bangsa (Mrk. 13:10). Pendamping (parakletos) untuk melaksanakan tugas ini adalah Roh Kudus, sementara agen pelaksana yang dipilih secara ilahi untuk memproklamasikan Injil adalah gereja Yesus Kristus. ${ }^{27}$ Gereja adalah ciptaan baru yang didirikan oleh Tuhan Yesus yang dipersiapkan untuk memberitakan perbuatan Tuhan yang ajaib, olehnya gereja sejati haruslah ditandai dengan misi, menjadi gereja yang missioner.

${ }^{23}$ Ibid, hlm. 669.

${ }^{24}$ Ibid, hlm. 670.

${ }^{25} \mathrm{Ibid}, \mathrm{hlm} .671$.

${ }^{26}$ Bambang Eko Putranto, Modul Kuliah Misi Pertumbuhan Gereja (Yogyakarta, 2002), hlm. 2.

${ }^{27}$ George W. Peters, Teologi Alkitabiah Tentang Pekabaran Injil, Cetakan Ke. (Malang: Penerbit Gandum Mas Malang, 2020), hlm. 243. 
Tanda Kelima dari gereja sejati adalah kesatuan yang nyata dalam doa Tuhan Yesus: "Dan bukan untuk mereka ini saja Aku berdoa, tetapi juga untuk orang-orang, yang percaya kepada-Ku oleh pemberitaan mereka; supaya mereka semua menjadi satu, sama seperti Engkau, ya Bapa, di dalam Aku dan Aku di dalam Engkau, agar mereka juga di dalam Kita, supaya dunia percaya, bahwa Engkaulah yang telah mengutus Aku. Dan Aku telah memberikan kepada mereka kemuliaan, yang Engkau berikan kepada-Ku, supaya mereka menjadi satu, sama seperti Kita adalah satu: Aku di dalam mereka dan Engkau di dalam Aku supaya mereka sempurna menjadi satu, agar dunia tahu, bahwa Engkau yang telah mengutus Aku dan bahwa Engkau mengasihi mereka, sama seperti Engkau mengasihi Aku. "(Yohanes 17:21-23).

Kesatuan yang dimaksud bukanlah kesatuan denominasional atau organisasional, juga bukan kesatuan konformitas (penyesuaian) yang merupakan pendekatan kepada gereja yang akan membuat setiap orang sama. Kesatuan yang dimaksudkan oleh Tuhan Yesus adalah kesatuan yang beranalogi dengan kesatuan yang eksis di dalam ke-Allah-an (Yoh. 17:21,23). Gereja harus memiliki kesatuan rohani yang mencakup orientasi dasar, keinginan-keinginan, dan kehendak dari orang-orang yang berpartisipasi. ${ }^{28}$ Dari penjelasan diatas, nyata bahwa kesatuan adalah tanda gereja sejati, dimana seperti tandatanda lainnya kesatuan adalah sesuatu yang diberikan kepada gereja, tetapi juga sesuatu yang harus diupayakan oleh gereja sejati.

Tanda keenam dari gereja sejati adalah kasih, dimana kasih merupakan tanda yang memberi arti kepada orang-orang lain dan yang tanpanya gereja tidak mungkin menjadi seperti yang Allah maksudkan. ${ }^{29}$ Gereja yang penuh dengan kasih adalah kehendak Tuhan seperti tertulis dalam Firman Tuhan: "dan Aku telah memberitahukan nama-Mu kepada mereka dan Aku akan memberitahukannya, supaya kasih yang Engkau berikan kepada-Ku ada di dalam mereka dan Aku di dalam mereka." (Yohanes 17:26). Dalam pasal yang berbeda, Yohanes menulis: "Aku memberikan perintah baru kepada kamu, yaitu supaya kamu saling mengasihi; sama seperti Aku telah mengasihi kamu demikian pula kamu harus saling mengasihi. Dengan demikian semua orang akan tahu, bahwa kamu adalah muridmurid-Ku, yaitu jikalau kamu saling mengasihi." (Yoh. 13:34-35). Kasihlah yang mampu mengikat dan memberikan keseimbangan dari tanda-tanda gereja sejati lainnya. Sukacita, kekudusan, kebenaran, misi dan kesatuan dan tanda lainnya hanya akan bersifat ekslusif serta tak bermanfaat bagi orang lain tanpa adanya kasih. Olehnya, kasih merupakan tanda gereja sejati.

Tanda ketujuh adalah memberitakan firman dengan benar. ${ }^{30}$ meskipun berbedabeda secara teologi dan didalam tingkatan kemurnian doktrin, gereja yang sejati mengakui semua hal yang esensial bagi iman, seperti keilahian Kristus, Tritunggal, pembenaran karena iman, penebusan Kristus atau doktrin lain yang esensial. ${ }^{31}$ Gereja boleh memiliki

\footnotetext{
${ }^{28}$ Boice, Dasar-Dasar Iman Kristen (Foundations of Christian Faith), hlm. 674.

${ }^{29}$ Ibid.

${ }^{30}$ Sproul, Kebenaran-Kebenaran Dasar Iman Kristen, hlm. 289.

${ }^{31}$ Ibid.
} 
perbedaan dalam beberapa hal, namun haruslah memiliki pusat yang sama seperti dirumuskan oleh Dewan Gereja-gereja se-dunia seperti dikutib oleh Soedarmo: "Pemberitaan yang murni tentang Yesus Kristus sebagai Allah dan Juruselamat". ${ }^{32}$ Hal-hal yang tidak esensial secara iman, seperti liturgi, pakaian dan alat-alat musik gerejawi bisa saja berbeda sesuai dengan konteks budaya masing-masing.

Pemberitaan Firman yang benar merupakan sarana yang amat besar untuk mempertahankan gereja dan memungkinkan gereja menjadi ibu bagi setiap orang percaya. ${ }^{33}$ Pemberitaan Firman yang benar merupakan ciri khas dari gereja yang benar (Yoh. 8:31, 32, 47; 14:23; 1 Yoh. 4:1-3; 2 Yoh. 9). Tanda ini penting bagi gereja sejati, sekalipun tentu susah untuk mencapai tingkat kesempurnaan seperti diatas, namun setidaknya gereja berupaya untuk sungguh-sungguh mengikuti tuntunan Firman Tuhan.

Tanda kedelapan dari gereja sejati adalah pelaksanaan sakramen-sakramen secara benar. ${ }^{34}$ Gereja menekankan pengenangan melaui sakramen yaitu dari pembaptisan Yesus dan Perjamuan Kudus sebagai bentuk untuk mengenang Kristus. ${ }^{35}$ Gereja yang menyangkali atau menyepelekan sakramen yang diperintahkan oleh Kristus merupakan gereja yang salah. Gereja yang melecehkan pelaksanaan Perjamuan Tuhan dengan mengijinkan orang yang belum percaya untuk mengikuti Perjamuan Kudus bukanlah gereja yang sejati. ${ }^{36}$ Berkhof menulis bahwa sakramen-sakramen tidak boleh dipisahkan dari Firman Tuhan sebab sakramen itu tidak memiliki isi pada dirinya sendiri, tetapi endapatkannya dalam Firman Tuhan. ${ }^{37}$ Menyadari pentingnya pelaksanaan sakramen secara benar dalam gereja, maka sakramen harus dilaksanakan oleh orang-orang yang memiliki kualifikasi tepat sebagaimana Firman Tuhan baik rohaniawan yang melayani maupun jemaat yang mendapatkan pelayanan. Pada akhirnya dapat dikatakan bahwa pelaksanaan sakramen dengan tepat dan benar adalah tanda dari gereja sejati yang mana hal ini muncul dari hubungan yang tak terpisahkan dengan pemberitaan Firman yang benar (Mat. 28:19; Mrk. 16:15; Kis. 2:42; 1 Kor. 11:23,30).

Tanda kesembilan dari gereja sejati adalah pelaksanaan disiplin gereja ${ }^{38}$ Senada dengan Sproul, Berkhof menulis bahwa disiplin gereja sangat penting untuk menjaga kemurnian doktrin dan kesucian sakramen. ${ }^{39}$ Oleh Gereja yang tidak melaksanakan disiplin cepat atau lambat akan terdegradasi kebenaran dan kesuciannya. karena itu, gereja yang mau mempertahankan kebenaran harus rajin dan tekun melaksanakan disiplin Kristen, seperti tuntunan Firman Tuhan (Mat. 18:18; 1 Kor. 5:1-5; 13; 14:33, 40; Why. 2:14, 15, 20).

${ }^{32}$ Soedarmo, Ikhtisar Dogmatika, Ihlm. 226.

${ }^{33}$ Berkhof, Teologi Sistematika 5, hlm. 49.

${ }^{34}$ Sproul, Kebenaran-Kebenaran Dasar Iman Kristen, hlm.289.

${ }^{35}$ David R. Ray, Gereja Yang Hidup, ed. Nino Oktorino Eko Y.A. Fangohoy, Steve Gaspersz, Cetakan ke. (Jakarta: BPK Gunung Mulia, 2009), hlm. 203.

${ }^{36}$ Sproul, Kebenaran-Kebenaran Dasar Iman Kristen.

${ }^{37}$ Berkhof, Teologi Sistematika 5, hlm. 50.

${ }^{38}$ Sproul, Kebenaran-Kebenaran Dasar Iman Kristen, hlm. 290.

${ }^{39}$ Berkhof, Teologi Sistematika 5, hlm. 51. 


\section{Aplikasi Gereja Sejati Bagi Pelayanan Gereja Kontemporer}

Kata gereja berasal dari bahasa Yunani " $\varepsilon \kappa \kappa \lambda \varepsilon \sigma \iota \alpha$ " ekklesia yang artinya mereka yang dipanggil keluar. ${ }^{40}$ Dengan pengertian ini, maka gereja adalah persekutuan orangorang pilihan yang sudah dipanggil keluar dari lingkungannya yang gelap. Pada waktu yang sama mereka juga memiliki panggilan spiritual yang biasa disebut sebagai amanat agung untuk menjadi garam dan terang di sekitarnya (Matius 5:13-14). Oleh sebab itu gereja kontemporer haruslah menunjukkan jatidirinya sebagai gereja sejati sesuai dengan Firman Tuhan yang telah penulis paparkan diatas, sebagai langkah aplikatif dari tanda gereja sejati bagi pelayanan gereja kontemporer.

Pertama: Pelayanan gereja kontemporer dilakukan dengan penuh sukacita. Sebagaimana tanda pertama dari gereja sejati adalah sukacita, maka sudah selayaknyalah gereja kontemporer mendasarkan seluruh totalitas pelayanan gerejawi dengan penuh sukacita. Sukacita mewarnai seluruh aspek kehidupan pelayanan gerejawi, baik pelayanan internal gereja maupun pelayanan keluar gereja. Dengan tanda pertama ini, gereja kontemporer yang telah dipenuhi sukacita berkat persekutuan dengan Tuhan, harus memancarkan sukacita ini bagi orang lain. Gereja kontemporer memiliki tanggung jawab untuk saling menghibur satu sama lain. ${ }^{41}$ Rasul Paulus memberikan satu cara yang jitu dalam menghibur satu dengan yang lain, yaitu dengan mengingatkan keberadaan eskatologis orang percaya. Paulus menulis kepada jemaat di Tesalonika untuk menjelaskan apa arti kedatangan kembali Kristus dalam kaitannya dengan orang percaya baik yang masih hidup maupun yang sudah mati di dalam Kristus.

Kedua: gereja kontemporer haruslah hidup dalam kekudusan. Sebagaimana kekudusan merupakan tanda gereja sejati, maka gereja kontemporer haruslah hidup dalam kekudusan, baik secara personal maupun komunal. Gereja kontemporer harus menjadi umat yang kudus (1 Pet. 2:9), karena tanpa kekudusan tak seorangpun dapat melihat Allah (Ibr. 12:14).

Ketiga: gereja kontemporer haruslah hidup dalam kebenaran. Gereja harus semakin bertumbuh didalam ke-Kristenan dengan hidup kudus berdasarkan Firman kebenaran. Satu-satunya cara supaya gereja hidup dalam kebenaran adalah dengan menerapkan kebenaran Allah yang dicatat dalam Alkitab.

Keempat: gereja kontemporer haruslah menjadi gereja yang missioner. Sebagaimana penulis paparkan diatas bahwa gereja missioner adalah gereja yang percaya penuh kepada Yesus Kristus sebagai Tuhan dan Juruselamat, dan memiliki semangat yang penuh untuk memberitakan keselamatan kepada orang lain. Kata gereja berasal dari bahasa Yunani “ $\varepsilon \kappa \kappa \lambda \varepsilon \sigma \iota \alpha$ " ekklesia yang artinya mereka yang dipanggil keluar. ${ }^{42}$ Dengan pengertian ini, maka gereja adalah persekutuan orang-orang pilihan yang sudah dipanggil

\footnotetext{
${ }^{40}$ Harianto GP, Teologi Misi Dari Misio Dei Menuju Misio Ecclesia (Yogyakarta: Penerbit Andi Offset, 2017).

${ }^{41}$ Boice, Dasar-Dasar Iman Kristen (Foundations of Christian Faith, hlm. 751).

${ }^{42}$ GP, Teologi Misi Dari Misio Dei Menuju Misio Ecclesia.
} 
keluar dari lingkungannya yang gelap. Pada waktu yang sama mereka juga memiliki panggilan spiritual yang biasa disebut sebagai amanat agung untuk menjadi garam dan terang di sekitarnya (Matius 5:13-14).

Dengan kerangka berpikir tersebut, sudah seharusnya gereja memiliki antusiasme bukan percaya sepenuh kepada Kristus namun juga memiliki semangat yang penuh untuk memberitakannya kepada orang lain yang masih tinggal dalam kegelapan. Gene Getz seperti dikutib oleh Montgomery menulis bahwa tiga pengalaman penting untuk bertumbuh sebagai orang Kristen yang matang adalah ajaran Alkitab yang baik yang memberikan stabilitas teologis dan rohani, hubungan-hubungan yang mendalam dan memuaskan antara sesama tubuh Kristus dan dengan Kristus dan pengalaman melihat orang banyak datang kepada Yesus sebagai hasil kesaksian korporat dan individual kepada dunia yang bukan Kristen. ${ }^{43}$ Gereja kontemporer adalah haruslah menjadi ereja missioner.

Kelima: gereja kontemporer adalah gereja yang hidup dalam kesatuan. Gereja memiliki karakter yang internal dan spiritual, dimana karakter ini merupakan kesatuan mistis dari tubuh Kristus, dimana anggotanya adalah orang percaya. ${ }^{44}$ Tubuh ini diatur oleh satu Kepala yaitu Yesus Kristus, yang adalah Raja Gereja, dan dihidupkan oleh satu Roh, yaitu Roh Kristus. Sebagaimana penulis paparkan diatas bahwa kesatuan yang dimaksud bukanlah kesatuan denominasional atau organisasional, juga bukan kesatuan konformitas (penyesuaian) yang merupakan pendekatan kepada gereja yang akan membuat setiap orang sama, melainkan kesatuan rohani.

Keenam: gereja kontemporer haruslah hidup penuh kasih. Kasih adalah intisari dari ajaran Kristus, bahkan dari seluruh 66 kitab Perjanjian Lama dan Perjanjian Baru jika diperas maka tetesan terakhir dari perasan tersebut adalah kasih. Hal tersebut nyata dalam dialog antara Tuhan Yesus dan orang Farisi seperti berikut ini:"Guru, hukum manakah yang terutama dalam hukum Taurat?"Jawab Yesus kepadanya: "Kasihilah Tuhan, Allahmu, dengan segenap hatimu dan dengan segenap jiwamu dan dengan segenap akal budimu. Itulah hukum yang terutama dan yang pertama. Dan hukum yang kedua, yang sama dengan itu, ialah: Kasihilah sesamamu manusia seperti dirimu sendiri.

Pada kedua hukum inilah tergantung seluruh hukum Taurat dan kitab para nabi."

(Matius 22:36-40). Dari dialog tersebut, nyata bahwa kasih merupakan intisari ajaran Kristus, kasih merupakan denyut nadi Kristus, kasih merupakan detak jantung Kristus. Olehnya gereja masa kini haruslah menjadi gereja yang penuh kasih, baik kasih kepada Allah maupun kasih kepada sesama.

Ketujuh: Gereja kontemporer haruslah memberitakan Firman Tuhan dengan benar. Ditengah maraknya rupa-rupa pengajaran yang menyesatkan bahwa munculnya berbagai bidat Kristen, gereja haruslah tampil dengan pengajaran yang benar. Pengajaran Firman yang benar sudah menjadi ciri dari gereja mula-mula, seperti tertulis dalam Firman Tuhan: "Mereka bertekun dalam pengajaran rasul-rasul dan dalam persekutuan. Dan mereka selalu berkumpul untuk memecahkan roti dan berdoa." (Kis. 2:42). Pengajaran Firman Tuhan

\footnotetext{
${ }^{43}$ Boice, Dasar-Dasar Iman Kristen (Foundations of Christian Faith), hlm. 753.

${ }^{44}$ Berkhof, Teologi Sistematika 5, hlm. 40.
} 
dengan benar harus dilaksanakan dengan sepenuh hati, kekuatan dan akal budi baik dalam hal konten atau isi pengajaran, motivasi memberitakan Firman, maupaun cara memberitakan Firman.

Kedelapan: gereja kontemporer haruslah melaksanakan sakramen dengan benar. Pelaksanaan sakramen secara benar penting untuk dilakukan oleh gereja kontemporer karena beberapa alasan diantaranya: sakramen-sakramen adalah ordinansi ilahi yang ditetapkan oleh Kristus sendiri, baik Perjamuan Kudus maupun baptisan Air. Sakramensakramen adalah ordinansi dimana unsur-unsur material digunakan sebagai tanda-tanda yang kelihatan dari berkat Allah. Ketiga, sakramen adalah sarana anugrah bagi orang yang dengan cara yang layak mengambil bagian dalam sakramen itu. Ke-empat, Sakramen adalah meterai, sertifikasi atau konfirmasi bagi kita akan anugrah yang sakramen-sakramen itu tandai. ${ }^{45}$

Kesembilan: gereja kontemporer harus menjalankan disiplin/siasat gereja. Siasat/disiplin gereja penting dilakukan untuk menjaga wibawa gereja juga untuk menjaga kawanan domba atau jemaat dari hal yang tidak berkenan kepada Allah. Disiplin gereja dapat dipakai untuk menjaga gereja supaya tidak terkontaminasi oleh pengajaran yang menyesatkan dan juga menjaga umat dari pengaruh dosa yang menjijikkan.

\section{Kesimpulan}

Setelah penulis memaparkan berbagai fakta diatas, maka penulis menyimpulkan bahwa Unsur-unsur dalam Perjanjian Lama ada dalam gereja Perjanjian Baru, namun demikian tidak dapat disamakan dengan tepat antara Jemaah Perjanjian Lama dengan gereja, oleh karena gereja adalah sesuatu produk baru yang didirikan diatas Tuhan Yesus, dijadikan oleh Roh Kudus dan berisi orang-orang dari segala ras dari seluruh bangsa.

Gereja adalah kumpulan orang-orang yang dipanggil keluar ke dalam persekutuan dengan Kristus, yang secara aktif beriman dan menghayati kehidupan iman sesuai tuntunan Firman Tuhan dan pimpinan Roh Kudus, yang begabung dalam persekutuan universal di Surga dan dibumi, yang kelihatan dan yang berkumpul secara terus menerus dilokalitas tertentu. Gereja yang sejati memiliki 9 (Sembilan) ciri utama yaitu: sukacita (Yoh. 17: 13), kekudusan (Yoh. 17:14-16), kebenaran (Yoh. 17: 17), misi (Yoh. 17: 18), kesatuan (Yoh. 17: 21-23) dan kasih (Yoh. 17: 26), memberitakan Firman Tuhan dengan benar, menggunakan sakramen dengan benar, dan menjalankan disiplin gereja. Tanda-tanda gereja sejati tersebut dapat diaplikasikan dalam pelayanan gereja kontemporer. Gereja kontemporer haruslah gereja yang penuh sukacita hidup dalam kekudusan, hidup dalam kebenaran, menjadi gereja yang missioner, hidup dalam kesatuan, hidup penuh kasih, memiliki pengajaran yang benar, melaksanakan sakramen secara benar dan menjalankan disiplin/siaat gereja sesuai dengan tuntunan Firman Tuhan.

${ }^{45}$ Boice, Dasar-Dasar Iman Kristen (Foundations of Christian Faith, hlm. 688-690). 


\section{Daftar Pustaka}

Berkhof, Louis. Teologi Sistematika 5. Edited by Rudy dan Hendry. Cetakan Ke. Surabaya: Penerbit Momentum (Momentum Christian Literature), 2001.

Boice, James Montgomery. Dasar-Dasar Iman Kristen (Foundations of Christian Faith). Edited by Solomon Yo. Cetakan Ke. Surabaya: Penerbit Momentum (Momentum Christian Literature), 2015.

G.C. Van Niftrik, B.J. Boland. Dogmatika Masa Kini. Edited by Staf Redaksi BPK Gunung Mulia. Cetakan ke. Jakarta: BPK Gunung Mulia, 2015.

GP, Harianto. Teologi Misi Dari Misio Dei Menuju Misio Ecclesia. Yogyakarta: Penerbit Andi Offset, 2017.

Henry C. Thiessen. Teologi Sistematika. Cetakan Ke. Malang: Penerbit Gandum Mas Malang, 2010.

Menzies, William W. dan Stanley M. Horton. Doktrin Alkitab. Cetakan ke. Malang: Penerbit Gandum Mas Malang, 1998.

Peters, George W. Teologi Alkitabiah Tentang Pekabaran Injil. Cetakan Ke. Malang: Penerbit Gandum Mas Malang, 2020.

Putranto, Bambang Eko. Modul Kuliah Misi Pertumbuhan Gereja. Yogyakarta, 2002.

Ray, David R. Gereja Yang Hidup. Edited by Nino Oktorino Eko Y.A. Fangohoy, Steve Gaspersz. Cetakan ke. Jakarta: BPK Gunung Mulia, 2009.

Ryrie, Charles. Teologi Dasar 1. Cetakan Ke. Yogyakarta: Yayasan Penerbit ANDI, 1991. Soedarmo, Dr. R. Ikhtisar Dogmatika. Edited by Staff Redaksi BPK Gunung Mulia. Cetakan ke. Jakarta: BPK Gunung Mulia, 2002.

Sproul, R.C. Kebenaran-Kebenaran Dasar Iman Kristen. Cetakan Ke. Malang: Departemen Literatur SAAT, 2002.

Zaluchu, Sonny Eli. "Eksegesis Kisah Para Rasul 2:42-47 Untuk Merumuskan Ciri Kehidupan Rohani Jemaat Mula-Mula Di Yerusalem." EPIGRAPHE: Jurnal Teologi dan Pelayanan Kristiani 2, no. 2 (2019): 72-82. 